Research Article

\title{
Molecular detection of aeromonas hydrophila as the main cause of outbreak in Tilapia farms in Egypt
}

\begin{abstract}
An outbreak recorded in Tilapia farms in Kafrelsheikh governorate with high mortalities ranged between $30-70 \%$ in the summer season of 2014 . This study was conducted for isolation and identification of the causative agent responsible for mortalities in four fish farms. Twelve Aeromonas isolates were identified by PCR using Aeromonas species primer at the molecular weight of (953 bp) then all strains were also confirmed by PCR as Aeromonas hydrophila using Aeromonas hydrophila specific-16S rRNA gene primer at the molecular weight of (103 bp).
\end{abstract}

Keywords: Oreochromis niloticus, Outbreak, Fish farm, PCR: Aeromonas hydrophila, Tilapia, mortality, Kafrelsheikh
Volume 2 Issue 6 - 2015

\author{
Ibrahim MAboyadak,' Nadia G MAli,' Ashraf \\ MAS Goda, ${ }^{2}$ Walaa $\mathrm{H}$ Aboelgalagel, ${ }^{3}$ Asmaa \\ ME Salam ${ }^{2}$ \\ 'Fish disease lab, National Institute of Oceanography and \\ Fishery (NIOF), Egypt \\ ${ }^{2}$ Aquaculture department, National Institute of Oceanography \\ and Fishery (NIOF), Egypt \\ ${ }^{3}$ Central Diagnostic \& Research Lab, Faculty of Veterinary \\ Medicine Kafrelsheikh University, Egypt
}

\begin{abstract}
Correspondence: Ibrahim M Aboyadak, Fish disease lab, National Institute of Oceanography and Fishery (NIOF), Alexandria, Egypt, Tel 00201005100472,

Email i.aboyadak@gmail.com
\end{abstract}

Received: August 05, 2015 | Published: September 30, 2015

\section{Introduction}

The global production of cultured tilapia represent 4.4 million ton in 2013. ${ }^{1}$ Egypt ranked as third major producer with total production of 635843 ton in $2013,{ }^{2}$ approximately, $14.45 \%$ of global cultured tilapia production. Kafrelsheikh is the main tilapia-culturing center in Egypt as it produces about 320 thousand ton, which represent $51.2 \%$ of Egyptian production and $7.27 \%$ of global production. Bacterial diseases are considered the main and most dangerous type of diseases affecting the fish production as it represents $80 \%$ of fish mortalities. ${ }^{3}$ Fish mortalities have a negative impact fish farming is not only provide a source of cheap animal protein and a source of income but also it is a source of employment. Continuous losses due, to fish mortalities may make fish farms owners to stop or change the activity that causes loss of thousands of worker to their jobs.

In Kafrelsheikh, the semi intensive tilapia culture is the only system used in earthen bonds, fish farms supplied with agricultural drain water, fish density in studied farms is four fish per cubic meter. The most common bacterial disease affecting fish is motile Aeromonas septicemia caused by Aeromonas hydrophila. It is defined as septicemic disease worldwide distributed affecting numerous species of freshwater and marine fishes. It is also considered as the most significant disease which occurs in cultured freshwater fish. ${ }^{4}$ Congestion and haemorrhages on the abdominal wall and at the base of fins with scale erosion at different parts of the body were the marked clinical signs observed by Assad ${ }^{5}$ who also recorded severe congestion of internal organs with accumulation of ascetic fluid in abdominal cavity and swollen kidney and spleen. In Egypt, motile Aeromonas septicemia has a potential economic hazard in which it causes severe losses in cultured freshwater fish including Oreochromis niloticus, common carp, Mugil cephalous and Mugilcapeto. ${ }^{6}$ Increasing water change elevation of water column highs and stop feeding helped in decreasing the deleterious effect of the outbreak but not solve the problem completely. So the present work aimed for the isolation and identification of the causative agent responsible for this outbreak in four tilapia farms in Kafrelsheikh by molecular detection using PCR.

\section{Materials and methods}

\section{Study area}

Samples were taken from four fish farms suffered from mass mortalitiesin Kafrelsheikh governorate north of Egypt. First farm located in Baltim, second farm in Torombat seven and other two farms in Elhamol.

Sample: Sixteen live Nile tilapias (Oreochromis niloticus) showing the clinical signs of septicemia were sampled, as four fish were taken from each farm. Each fish weight ranged between 150-500 gm. Each fish was packed alive in a separate stile labeled plastic bag and transported to labin ice pox.

Clinical examination: The clinical examination was performed according to the method described by Conroy \& Hermann. ${ }^{6}$

Post mortem examination: The post mortem examination was performed according to the method described by Austin \& Austin. ${ }^{7}$

Isolation and identification of the causative agent: Under sterile conditions one trypticsoy broth (Oxoid)tube was inoculated with a platinal lope from heart blood, liver and kidney tissues of fish and incubated at $37^{\circ} \mathrm{C}$ for $18 \mathrm{hrs}$. Rimler-Shotts media with novobiocin selective supplement (Oxoid) plates were streaked with a loopful of cultured broth then incubated at $37^{\circ} \mathrm{C}$ for $24 \mathrm{hrs}$. The growing colonies were further identified by PCR.

The isolates not grown on: Rimler-Shotts media were cultured on trypticsoy agar (Oxoid), the recovered colonies were stained with Gram stain.

\section{Identification of collected strains using PCR}

DNA extraction: Extraction of bacterial DNA was performed by thermolysis according to the method described by Ahmed et al. ${ }^{8} 100 \mu 1$ of overnight cultured broth was mixed with $400 \mu$ of sterile distilled water in eppendorf tubes that was transferred to the heat block for 5 mins at $95^{\circ} \mathrm{C}$ followed by centrifugation at $15000 \mathrm{rpm}$ for $2 \mathrm{~min}$ at 
$4^{\circ} \mathrm{C}$, the supernatant was used as DNA template and stored at $-20^{\circ} \mathrm{C}$ for PCR study (Table 1).

Table I Primers used for detection of Aeromonas species and Aeromonas hydrophila

\begin{tabular}{llll}
\hline Target & $\begin{array}{l}\text { Primer } \\
\text { name }\end{array}$ & Oligonucleotide sequence (5'-3') & Size (Bp) \\
\hline Aeromonas & AER-F & CTA CTT TTG CCG GCG AGC GG & \multirow{2}{*}{953 bp } \\
species & AER-R & TGA TTC CCG AAG GCA CTC CC & \\
Aeromonas & I6SrRNA-F & GGCCTTGCGCGATTGTATAT & \multirow{2}{*}{103 bp } \\
hydrophila & I6SrRNA-R & GTGGCGGATCATCTTCTCAGA & \\
\hline
\end{tabular}

\section{PCR amplification of targeted DNA:}

PCR mixture for both reactions (detection of Aeromonas species and Aeromonas hydrophila): Reactions were performed in a total volume of $25 \mu \mathrm{l}$. Each volume containing, $5 \mu \mathrm{l}$ of $5 \mathrm{X}$ master mix (taql/high yield- Jena Bioscience, Jena, Germany, consists of DNA polymerase, dNTPs mixture, (NH4) SO4, MgCl2, Tween 20, Nonidet P-40, stabilizers $+1.25 \mu \mathrm{l}$ of each primer (forward and transverse) $(20$ $\mathrm{pmol} / \mu \mathrm{l}),+5 \mu \mathrm{l}$ of genomic DNA $+12.5 \mu \mathrm{l}$ double deionized distilled water.

\section{Thermal cycle adjustment for:}

Amplification of Aeromonas species targeted DNA as described by Lee et al.'.' Amplification was carried out in thermal cycler (Peltier thermal cycler Model: MG 96+ enzyme ${ }^{\circledR}$ USA), with an initial denaturation at $94^{\circ} \mathrm{C}$ for 4 mins followed by 35 cycles of denaturation each at $94^{\circ} \mathrm{C}$ for $1 \mathrm{~min}$, annealing at $68^{\circ} \mathrm{C}$ for $30 \mathrm{sec}$ and an extension step at $72^{\circ} \mathrm{C}$ for $45 \mathrm{sec}$. After the end of cycle's one final extension step at $72^{\circ} \mathrm{C}$ for 10 mins was performed.

Amplification of Aeromonas hydrophila targeted DNA (specific16S rRNA gene as described by Trankhan et al. ${ }^{10}$ : Amplification was carried out in thermal cycler, with an initial denaturation at $94^{\circ} \mathrm{C}$ for 2 mins, followed by 35 cycles of denaturation, each at $94^{\circ} \mathrm{C}$ for 30 sec, annealing at $55.5^{\circ} \mathrm{C}$ for $30 \mathrm{sec}$ and an extension step at $72^{\circ} \mathrm{C}$ for $30 \mathrm{sec}$, After the end of cycles one final extension step at $72^{\circ} \mathrm{C}$ for 10 mins was performed.

\section{DNA assay}

DNA was assayed by agarose gel-electrophoresis, $5 \mu 1$ of PCR products were electrophoresed on 1.5\% agarose gels for Aeromonas spp. \& 2\% agarose gels for Aeromonas hydrophila. The agarose gels supplied with $0.6 \mu \mathrm{g} / \mathrm{ml}$ ethidiumbromidein $1 \mathrm{X}$ tris acetate EDTA buffer in gel electrophoresis apparatus (SCIE-PLAS, UK). DNA bands were visualized over a UV transilluminator (Winpact Scientific, USA).

\section{Results and discussion}

Clinical examination of diseased fish samples revealed presence of general signs of septicemiaincluding hemorrhagic patches on the skin, base of pectoral fin and around anal opening. Scale desquamation and skin ulcerations observed with fin erosions. Uni and bilateral exophthalmia with abdominal ascitis in some samples are present (Figure $1 \& 2$ ). The observed clinical signs were similar to that described by Asaad, ${ }^{5}$ Lewbart ${ }^{11}$ and Aboyadak. ${ }^{12}$ The clinical signs observed on infected fish including hemorrhagic patches can be attributed to both bacterial invasion and colonization also, to toxins produced by invading microorganism.Postmortem examination revealed presence of severe enteritis with sloughing of intestinal mucosa. Yellow ascetic fluid in the abdominal cavity of some samples was observed. Liver was congested and in some cases was pale enlarged with distended gall bladder. Spleen was enlarged and congested (Figure $3 \& 4$ ). The described Postmortem lesions were in agreement with the results described by Asaad, ${ }^{5}$ Aboyadak, ${ }^{12}$ Huizinga et al. ${ }^{13}$ and AOAD. ${ }^{14}$ The internal lesions appeared on infected fish were attributed to both bacterial invasion and colonization also, to its produced toxins described by Boulanger et al. ${ }^{15}$ Twelve from sixteen isolate were grown on R-S media giving small yellow colonies which are characteristic for Aeromonas hydrophila as described by Cipriano $^{16}$ and for confirmation PCR identification was performed.

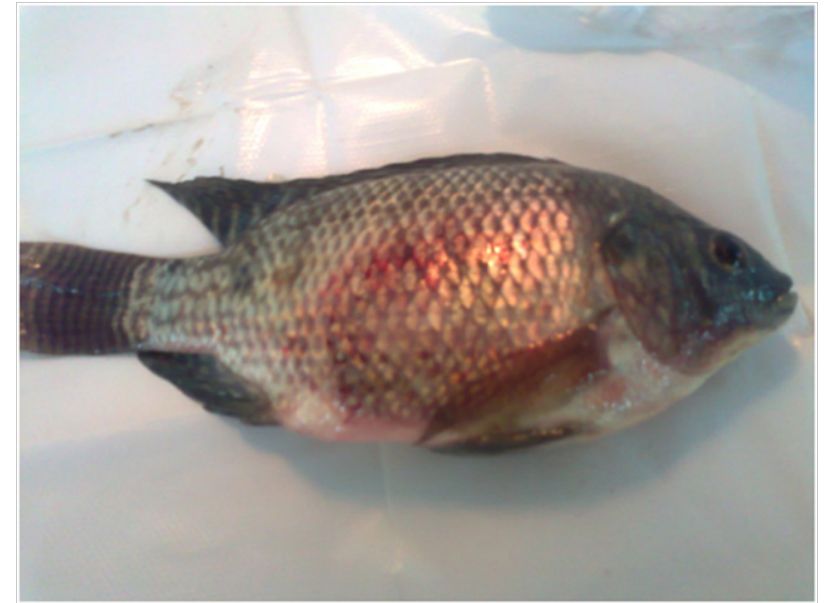

Figure I Oreochromis niloticus naturally infected with Aeromonas hydrophila showing skin hemorrhage.

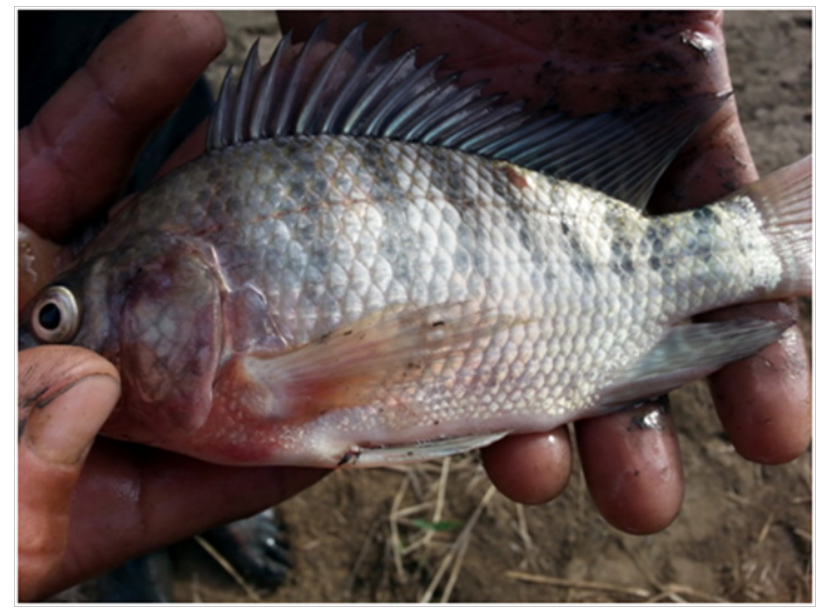

Figure 2 Oreochromis niloticus naturally infected with Aeromonas hydrophila showing skin hemorrhage at the base of pectoral fin with hemorrhagic skin ulcer under the dorsal fin.

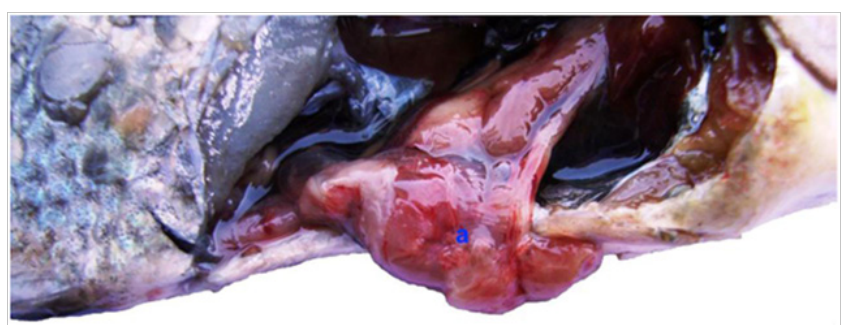

Figure 3 Oreochromis niloticus naturally infected with Aeromonas hydrophila showing severe enteritis, congestion and hemorrhages (a). 


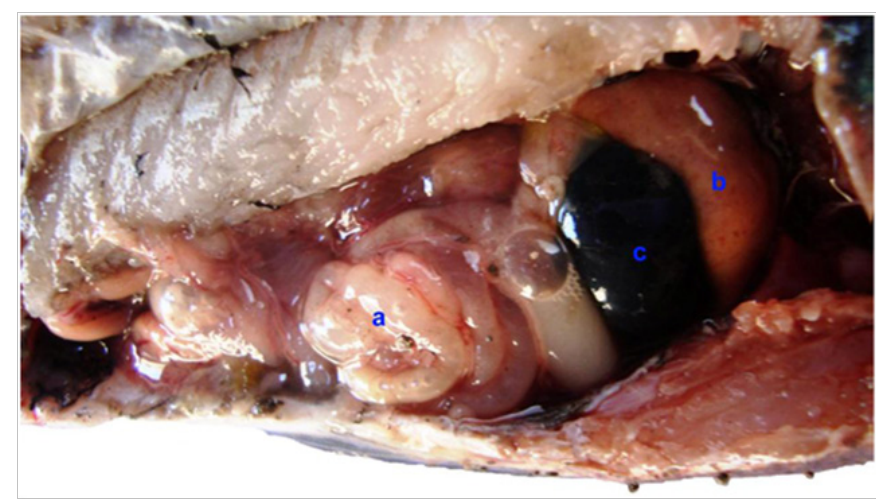

Figure 4 Oreochromis niloticus naturally infected with Aeromonas hydrophila showing enteritis, intestine filled with purulent exudates (a), pale enlarged liver (b) with enlarged gall bladder (c).

The PCR amplification with Aeromonas spp. specific primer identified twelve Aeromonas spp. isolate as specific band appeared by electrophoresis at a molecular weight of $953 \mathrm{bp}$ which is specific for Aeromonas spp. as showed in Figure 5 that was typically described by Lee et al. ${ }^{9}$ and Aboelgalagel. ${ }^{17}$ The PCR amplification using Aeromonas hydrophilaspecific primer (16S rRNA) identified twelve Aeromonas hydrophila strain as the PCR assay results in the amplification of $103 \mathrm{bp}$ band specific Aeromonas hydrophila, as showed in Figure 6. The same results were observed by Tarakhan et al., ${ }^{10}$ Aboelgalagel ${ }^{17}$ and Zakaria. ${ }^{18}$ Uncontrolled mortalities were recorded in several farms with different rearing facilities associated with high temperature occurred in July and August. Not only high temperature was recorded in this period, but also, high ammonia levels triggered the stability of rearing conditions of tilapia ponds. According to Irgeui et al. ${ }^{19}$ any change in water parameters will lead for immune stress conditions allowing bacterial infections to take place. The rest four isolates that not grow on Rimler-Shotts media were recultured on trypticsoy agar giving yellow colonies. Gram staining revealed filamentous long pleomorphic gram-negative rods that indicating the presence of Flavobacterium columnare. This bacterium isolated from cutaneous lesions (depigmented area) of affected fish (Figure 7) which was similar to that described by Cain \& Lafrentz. ${ }^{20}$ The culture characters of the causative agent and the PCR identification indicated that Aeromonas hydrophila was the major cause of the outbreak affecting tilapia farms in Kafrelsheikh governoratecausing high mortalities as the causative agent was isolated from three farms out of four examined farms in a total prevalence of $75 \%$.

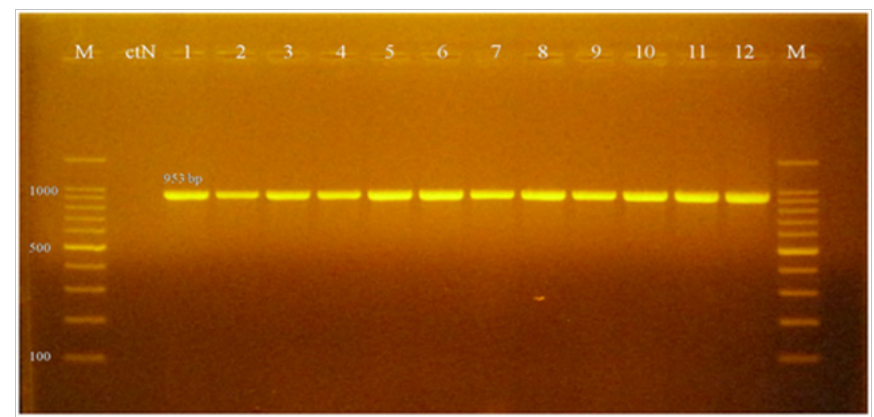

Figure 5 I.5\% Agarose gel electrophoresis of PCR product showing specific Aeromonas spp. bands at 953 bp.

M: 100 bp DNA size marker; ctN: control negative.

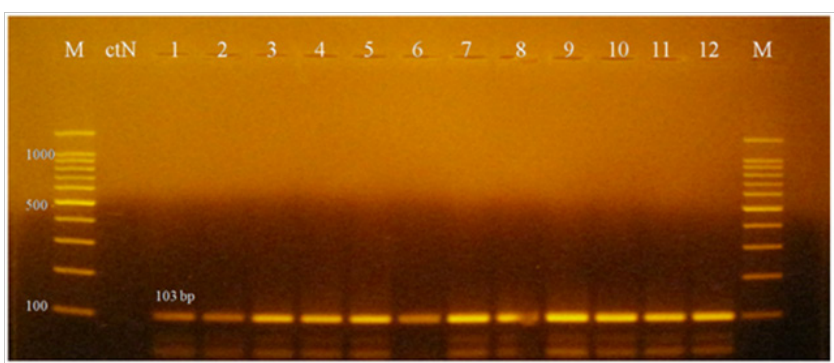

Figure $62 \%$ Agarose gel electrophoresis of PCR product showing specific Aeromonas hydrophila bands at 103 bp.

M: 100 bp DNA size marker; ctN: control negative.

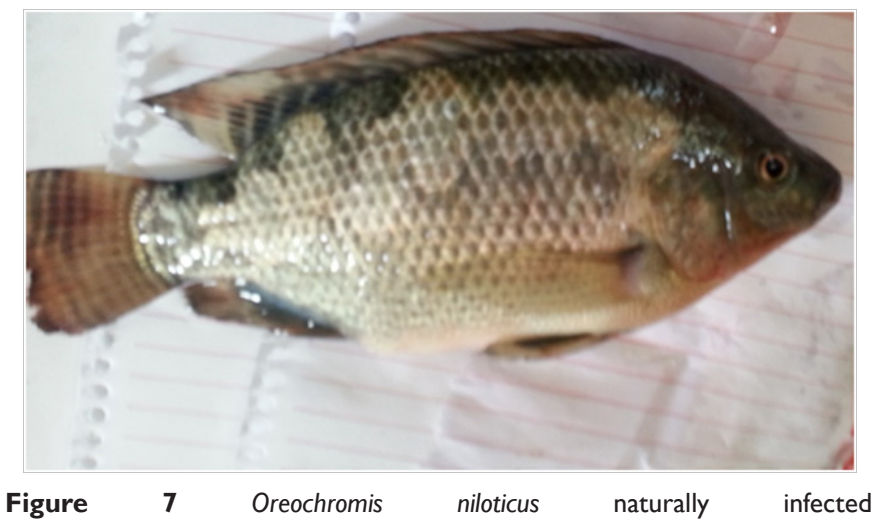

with Flavobacterium columnareshowing presence of depigmented areas in the dorsal fin, above the lateral line and at the caudal peduncle.

\section{Conclusion}

It could be concluded that Aeromonas hydrophila was the major cause of the outbreak affecting tilapia farms in Kafrelsheikh governoratein a total prevalence of $75 \%$.

\section{Acknowledgments}

None.

\section{Conflicts of interest}

None.

\section{References}

1. Tveteras R. Global Finfish, mussel production review growth continues, but slowing for main species. Global Aquaculture Advocate. 2014;17(6):8.

2. GAFRD. Fish Statistics yearbook 2013. 2014.

3. Zaki VH. Studies on Motile Aeromonas in freshwater fish with special emphasis to their toxigenic profile. MV Sc. Thesis, Alexandria University, Fac Vet Med, Egypt. 1991.

4. Aoki T. Motile Aeromonad (Aeromonas hydrophila). In: woo PTK \& Bruno DW (Eds), Fish Diseases and Disorders Volume 3 Viral, Bacterial and Fungal infections. CAB International, UK. 1999.

5. Asaad TMA. Bacteriological studies on Aeromonas hydrophilain fish in Kafr El-sheikh governorate. Thesis, Fac Vet Med, Kafr El-Sheikh University, Egypt. 2008.

6. Conroy DA, Hermann LR. Text book of fish diseases. T F H Pub, West Sylvania, USA. 1981 
7. Austin B, Austin DA. Bacterial fish pathogens, Diseases of Farmed and Wild Fish. (4th edn.), Springer Dordrecht Berlin Heidelberg, New York, USA. 2007.

8. Ahmed AM, Motoi Y, Sato M, et al. Zoo animals as a reservoir of gramnegative Bacteria Harboring Integrones and Antimicrobial Resistance Genes. Appl Environ Microbiol. 2007;73(20):6686-6690.

9. Lee C, Cho JC, Lee SH, et al. Distribution of Aeromonas spp. as identified by $16 \mathrm{~S}$ rDNA restriction fragment length polymorphism analysis in a trout farm. J Appl Microbiol. 2002;93(6):976-985.

10. Trakhna F, Harf-Monteil C, Abdelnour A, et al. Rapid Aeromonas hydrophila identification by TaqMan PCR assay: comparison with a phenotypic method. Lett Appl Microbiol. 2009;49(2):186-190.

11. Lewbart GA. Bacterial Diseases of Pet Fish. Michigan Veterinary Conference 2008. 2008 .

12. Aboyadak IMI. A study on the role of antibiotics in controlling Aeromonas hydrophila infection incultured freshwater fish. MV Sc Thesis, pharmacology, Faculty of Veterinary Medicine Kafrelsheikh University, Egypt. 2011.

13. Huizinga HW, Esch GW, Hazen TC. Histopathology of red sore disease (Aeromonas hydrophila) in naturally and experimentally infected largemouth bass Micropterus salmoides (Lacepede). J Fish Dis. 1979;2(4):263-277.
14. AOAD. Study on Fish Diseases in Arab Countries. Arab Organization for Agricultural Development publication. 2005.

15. Boulanger $\mathrm{Y}$, Lallier R, Cousineau G. Isolation of enterotoxigenic Aeromonas from fish. Can J Microbiol. 1977;23(9):1161-1164.

16. Cipriano RC. Aeromonas hydrophilaand motile aeromonas septicemia of fish. Fish Disease leaflet 68. US Geological Survey, Lee town Science Center, National Fish Health Research Laboratory 11700, USA. 2001.

17. Aboelgalagel WH. Bacteriological and molecular studies of some pathogenic bacteria isolated from Oreochromis niloticus in fish farms. MV Sc Thesis, Microbiology, Faculty of Veterinary Medicine Kafrelsheikh University, Egypt. 2015.

18. Zakaria AA. Molecular characterization of Aeromonas hydrophila strains isolated from diseased marine and freshwater fish. Ph D Thesis, Fish diseases and management, Faculty of Veterinary Medicine Kafrelsheikh University, Egypt. 2014.

19. Iregui CA, Comas J, Vásquez GM, et al. Experimental early pathogenesis of Streptococcus agalactiae infection in red tilapia Oreochromis spp. J Fish Dis. 2015.

20. Cain KD, LaFrentz BR. Laboratory maintenance of Flavobacterium psychrophilumand Flavobacterium columnare. Curr Protoc Microbiol Chapter 13: Unit 13B.1. 2007. 